Gvozdenović, S., Drakulović, D., Mandić, M. (2020): Seasonal dynamic of potentially toxic and toxic phytoplankton and biotoxins on mussel farm (Mytilus galloprovincialis Lamarck, 1819) in Kamenari - Boka Kotorska Bay. Agriculture and Forestry, 66 (4): 183-192.

DOI: 10.17707/AgricultForest.66.4.15

\author{
Slađana GVOZDENOVIĆ, Dragana DRAKULOVIĆ and Milica MANDIĆ ${ }^{I}$
}

\title{
SEASONAL DYNAMIC OF POTENTIALLY TOXIC AND TOXIC PHYTOPLANKTON AND BIOTOXINS ON MUSSEL FARM (Mytilus galloprovincialis Lamarck, 1819) IN KAMENARI - BOKA KOTORSKA BAY
}

\begin{abstract}
SUMMARY
Results about toxic and potentially toxic phytoplankton species and biotoxins are given in this paper. Investigation is conducted on mussel (Mytilus galloprovincialis Lamarck, 1819) farm situated in Kamenari (Tivat Bay) from January 2015 up to September 2016. In total six harmful phytoplankton taxons are identified, with clear seasonal variation in their abundance. Pseudo-nitzchia spp. were the most abundant (maximum abundace $1.1 \times 10^{5}$ cells/l), while Prorocentrum micans and $P$. cordatum reached maximum abundance up to $10^{3}$ cells/l during some seasons. Other toxic taxons had low abundance, while in some seasons were completely absent. Results about quantitative and qualitative analysis of biotoxins showed that all obtained values were below limit of detection (LOD), what implies on good quality of mussels meat on investigated farm, safe for human consumption.

Integrated monitoring of harmful phytoplankton and biotoxins should be continued in order to prevent possible negative consequences caused by increased growth of harmful algae (harmful algal blooms - HABs) and biotoxins.

Key Words: harmful phytoplankton, biotoxins, mussels, Boka Kotorska Bay, Adriatic Sea
\end{abstract}

\section{INTRODUCTION}

Boka Kotorska Bay is situated on southeastern part of Adriatic Sea. The Bay can be devided in three entities: Kotor-Risan Bay, Tivat Bay and Herceg Novi Bay (Mandić S. et al., 2016). It is semi-enclosed aquatorium with specific hydrography compare to open waters. Surrounded by karst Mountains (Orjen and Lovćen) the Bay is during winter and spring under influence of fresh water, what significantly affects physical, chemical and biological characteristic. Inflows of freshwater in Boka Kotorska Bay are numerous: rivers, springs, streams and

\footnotetext{
${ }^{1}$ Slađana Gvozdenović, (corresponding author: sladjanag@ucg.ac.me), Dragana Drakulović, Milica Mandić, University of Montenegro, Institute of Marine Biology, Put I bokeljske brigade 68, 85330 Kotor, MONTENEGRO

Notes: The authors declare that they have no conflicts of interest. Authorship Form signed online. 
submarine springs. Currents in the Bay depend on meteorological conditions (primary winds) and freshwater inflow from the coast and underwater sources (Bortoluzzi et al., 2016). Currents on the surface mainly depend on winds, while currents on the bottom layer depend on freshwater inflows (Bellafiore et al., 2011).

It is known that changes in physical and chemical parameters of water significantly affect phytoplankton. Temperature, salinity as well as nutrients $\left(\mathrm{SiO}_{4}^{-}, \mathrm{PO}_{4}^{3-}, \mathrm{NO}_{3}^{-}, \mathrm{NO}_{2}^{-}, \mathrm{P}, \mathrm{N}\right)$ are among most important parameters affecting quantitative and qualitative phytoplankton composition (Drakulović, 2012; Pestorić et al., 2019).

Diatoms and dinoflagellates are two main phytoplankton groups in marine ecosystems with crucial role in marine ecosystems as primary producers. There are about 300 phytoplankton species considered as harmful (Arapov, 2013). In general, regarding the effect they cause, harmful phytoplankton species can be observed as: high-biomass producers and toxin producers (Arapov, 2013). Phytoplankton toxins, also known as biotoxins, are associated with harmful algal blooms (HABs). HABs are influenced by a number of factors, including climate change and nutrient inputs from anthropogenic activities (Watson et al., 2015; Brooks et al., 2016). Due to increasing eutrophication around the world, HABs are occurring in more locations than ever before, and in contrast to large-scale blooms that are dominated by mesoscale circulation, Mediterranean HABs are more localized phenomenon, commonly related to areas of constrained dynamism, such as bays, lagoons, ports, beaches and estuaries (Ferrante et al., 2013).

Biotoxins can cause serious consequences and even death to aquatic organisms and humans (Visciano et al., 2016). Based on symptoms they cause in humans, biotoxins can be divided in six groups: diarrhetic shellfish poisoning (DSP), paralytic shellfish poisoning (PSP), amnesic shellfish poisoning (ASP), neurotoxic shellfish poisoning (NSP), azaspiracid shellfish poisoning (AZP) and cuguatera fish poisoning (CFP) (Arapov, 2013; Gvozdenović et al., 2015). Depending on their solubility, biotoxins can be classified as hydrophilic and lipophilic, where hydrophilic toxins involve ASP, PSP and the emerging pufferfish poisoning (PFP), while the lipophilic toxins are associated with DSP, AZP, as well as emerging CFP, NSP and cyclic imines (CIs) (Estevez et al., 2019). Europe Union legislation set regulatory limits for marine biotoxins (EC No. 853/2004; 854/2004; 15/2011, 786/2013).

Aquaculture is the fastes growing food production sector in the world, which can be serious affected by HABs and biotoxins. Because of that, different monitoring programmes (HABs and biotoxins monitoring) has been established worldwide.

In Montenegro exist about 20 farms all situated in area of Boka Kotorska Bay, where Mediterranean mussel (Mytilus galloprovincialis Lamarck, 1819) is dominant farming species (Mandić M. et al., 2016; Gvozdenović et al., 2017). Monitoring of qualitative and quantitative composition of toxic and potentially 
toxic phytoplankton on farms is continuously conducted by the Institute of Marine Biology, University of Montenegro, while biotoxins monitoring is continuous conducted by Center for Eco- Toxicological Research. This integrated monitoring give the possibility to react on time in order to prevent possible negative consequences caused by HABs and biotoxins.

The aim of this paper is to present results about seasonal dynamic of harmful phytoplankton and biotoxins on mussel farm in Kamenari.

\section{MATERIAL AND METHODS}

Investigation has been conducted from January 2015 up to September 2016 on mussel farm in Kamenari - Boka Kotorska Bay (Figure 1).

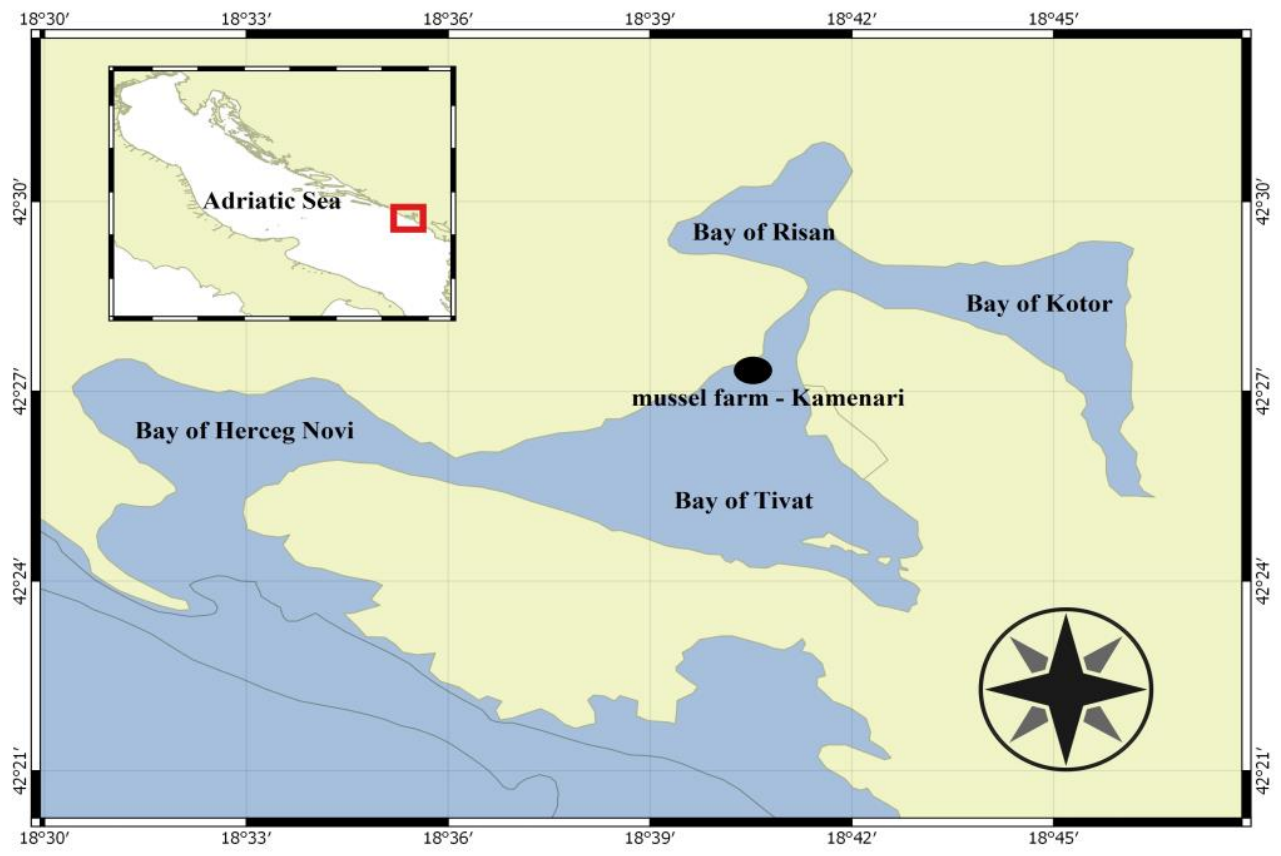

Figure 1. Map of Boka Kotorska Bay - black circle shows mussel farm situated in Kamenari

The farm is situated on the entrance of strait Verige which connect KotorRisan and Tivat Bay. Water sampling was done by ISO 5667-9:1992. Samples for analysis of temperature and salinity were taken by Niksin bottle between 2 and 3 $m$ depth, each month since January 2015 to September 2016. Temperature and salinity were measured in situ by CTD probe (Multiline P4; WTW). Samples for phytoplankton analysis were also taken by Niksin bottle between 2 and $3 \mathrm{~m}$ depth, seasonaly (winter 2015, spring 2015, summer 2015, autumn 2015, winter 2016, spring 2016, summer 2016). Phytoplankton analysis were done by standard method (MEST EN 15204:2014). Samples were preserved in 4\% formaldehyde. In laboratory, samples were dropped in $25 \mathrm{ml}$ chambers for sedimentation during 24 hours. Quantitative analysis (cells counting) were done using Leica DMI4000 
B inverted microscope in subsamples of $25 \mathrm{ml}$ (Utermöhl, 1958). Qualitative analysis involved using of keys for phytoplankton determination (Cupp, 1933; Hustedt, 1930; Peragallo and Peragallo, 1965; Dodge, 1985; Schiller, 1933; 1937; Sournia, 1989).

Mussels for biotoxins analysis were sampled monthly in line with Europe laboratory for marine biotoxins protocol. About $2 \mathrm{~kg}$ of mussels was sampled, soft tissue was separated from shell and frozen until analysis. ASP toxin analyse (domoic acid) was done according to Quilliam et al. (1995) protocol using HPLC-UV-DAD, while PSP toxins (STX, dcSTX, GTX1,4, GTX2,3, NEO, $\mathrm{C} 1,2)$ were analysed according to AOAC (2005) protocol using HPLC-FLD. Limit of detection (LOD) was calculated based on the standard deviation of the blank samples.

\section{RESULTS AND DISCUSSION}

Temperature and salinity values of sea water are given on Figure 2 . The minimum temperature was observed during January $2016\left(10.5^{\circ} \mathrm{C}\right)$, while the maximum temperature was measured during August $2015\left(26.5^{\circ} \mathrm{C}\right)$. Average water temperature during investigated period was $18.7^{\circ} \mathrm{C}$. Temperatures below $15{ }^{\circ} \mathrm{C}$ were present during winter months, while temperatures above $20^{\circ} \mathrm{C}$ were observed during summer months what is in accordiance to the other results obtained for the Boka Kotorska Bay (Drakulović et al., 2013; 2014; 2015).

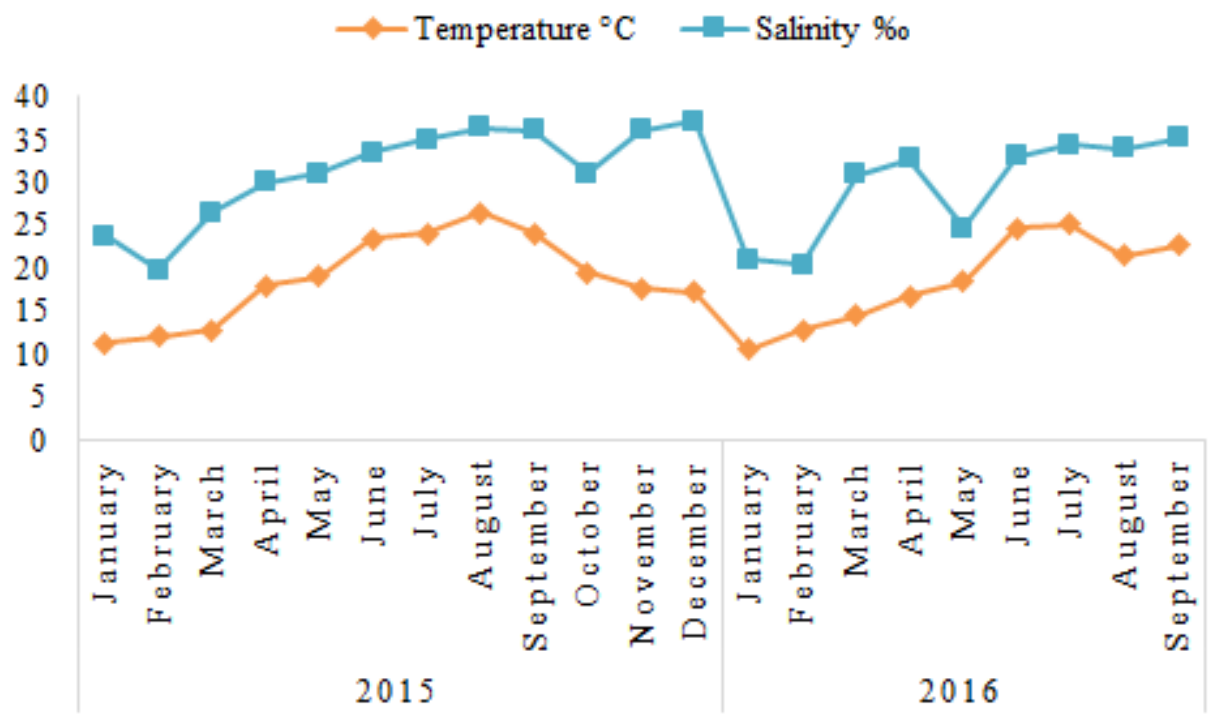

Figure 2. Temperature and salinity value of water on mussel farm in Kamenari during investigated period

Water salinity ranged from minimal value during February 2015 (19.8 \%o) up to maximum value during December 2015 (37.1\%). High salinity was also 
present during summer period. Average water salinity during investigated period was $30.6 \%$. Salinity is abiotic factor strongly affected and depended on freshwater inflow; higher salinity is mainly present during summer, while lower salinity is present during winter. Obtained results are in accordiance with other results obtained for the Bay (Drakulović et al., 2013; 2014; 2015), although maximum salinity value during December 2015 is not usual. These „extreme“ can be explained by quite warm and dry period during November and December 2015 with absence of rain.

Abundance of toxic and potentially toxic phytoplankton is presented on Figure 3. In total six taxons are identified. Five species belonged to dinofllagelates (Prorocentrum cordatum, P. micans, Phalacroma rotundatum, Lingulodinium polyedra and Dinophysis acuminata), while one taxon belonged to diatoms (Pseudo-nitzchia spp.). Results show seasonal variations in phytoplankton abundance. Pseudo-nitzchia spp. was the most abundant during all investigated seasons, except season winter 2016, when this taxon was absent. Maximum abundance of this taxon was during summer 2015 when reached values $1.1 \times 10^{5}$ cells/l. Prorocentrum cordatum and $P$. micans reached values up to $10^{3}$ cells/l during spring 2016 and summer 2016, respectively. Phalacroma rotundatum, Lingulodinium polyedra and Dinophysis acuminata had low abundance ranged from 40-80 cells/l, while during most seasons were absent.

Biotoxins analysis indicate absence of domoic acid and saxitoxins in mussles tissue, all obtained results were below LOD. LOD for all seven analysed biotoxins is given in Table 1.

Phytoplankton blooms are not just result of increased nutrients, other abiotic factors like temperature and freshwater inflow can also be a reason (Price et al., 2015; Ninčević Gladan et al., 2020). Dinoflagellates are the group that includes the largest number of harmful species which can cause blooms and biotoxins production. Drakulović (2012) indicated that abundance of toxic dinoflagellates in area of Boka Kotorska Bay is not alarmant.

Although results showed that Prorocentrum micans and P. cordatum did not exceed abundance above $10^{3}$ cells/1, Drakulović et al. (2012) reported abundance of $P$. micans in Boka Kotorska Bay in range of $10^{6}$ cells $/ 1$. For the same area, Bosak et al. (2011) indicate P. cordatum as dominant species in phytoplankton assemblage, with a maximum abundance $3.97 \times 10^{4}$ cells $/ 1$.

All five dinoflagellate species identified in this research are known to produce toxins as ocadaic acid and dinophysisitoxins, which can cause DSP in humans, as well as pectenotoxins and yessotoxins wich adverse effect in humans has not yet been confirmed (Arapov, 2013).

Pseudo-nitzchia spp. are known as dominant phytoplankton taxons among central and south Adriatic Sea (Burić et al., 2008). Pseudo-nitzchia spp. and Nitzschia spp. produce domoic acid which cause ASP in humans (Arapov, 2013; Gvozdenović et al., 2015). Ujević et al. (2010) indicate that toxic species do not always express toxicity, and if the abundance does not reach $1.0 \times 10^{5}$ cells $/ 1$, then the area can be considered safe with respect to ASP. 


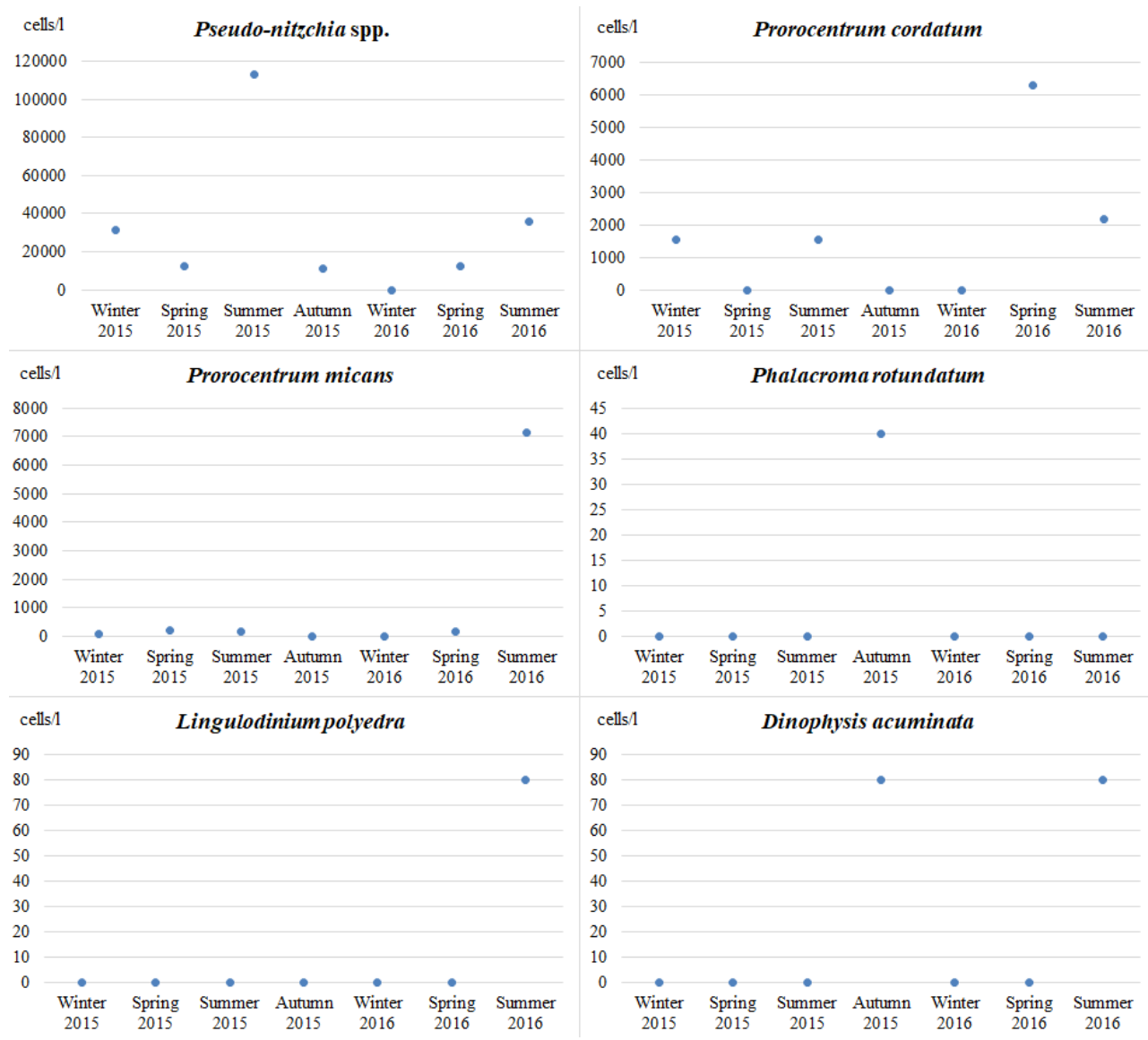

Figure 3. Seasonal dynamic of potentially toxic and toxic phytoplankton taxons on mussel farm in Kamenari

Table 1. LOD for all seven biotoxins

\begin{tabular}{ll}
\hline Biotoxin & LOD \\
\hline Domoic acid $(\mathrm{mg} / \mathrm{kg})$ & 0.326 \\
STX $(\mu \mathrm{g} / \mathrm{kg})$ & 51.42 \\
dcSTX $(\mu \mathrm{g} / \mathrm{kg})$ & 1.168 \\
GTX $1,4(\mu \mathrm{g} / \mathrm{kg})$ & 55.5 \\
GTX $2,3(\mu \mathrm{g} / \mathrm{kg})$ & 8.368 \\
NEO $(\mu \mathrm{g} / \mathrm{kg})$ & 43.9 \\
$\mathrm{C} 1,2(\mu \mathrm{g} / \mathrm{kg})$ & 7.368 \\
\hline
\end{tabular}

In this paper abundance of Pseudo-nitzchia spp. above $1.0 \times 10^{5}$ cells/l was just during summer 2015. Also in all mussel samples domoic acid was below LOD. Arapov et al. (2017) identified five potentially toxic species from genus Pseudo-nitzchia in central Adriatic Sea: $P$. calliantha, $P$. delicatissima, $P$. 
fraudulenta, $P$. pseudodelicatissima/ $P$. cuspidata and $P$. subfraudulenta, while in area of Kotor Bay, Bosak et al. (2010) identified P. calliantha. The same authors consider that blooms of this species appear in Kotor Bay.

Species from genus Alexandrium, as well as Gymnodinium catenatum and Pyrodinium bahamense are known to produce saxitoxins (Arapov, 2013; Gvozdenović et al., 2015). Toxic phytoplankton species which can produce saxitoxins have not been identified during investigation on farm in Kamenari. Additionally, those species have not ever been identified for Boka Kotorska Bay area (Drakulović, 2012; Drakulović et al., 2017). Obtained results are also supported by negative results of saxitoxins, as all six investigated saxitoxins in all mussel samples were below LOD.

Results of this paper are in accordiance to the results which are given by Pestorić et al. (2019) for mussel and fish farm in Orahovac which is also situated in area of Boka Kotorska Bay.

\section{CONCLUSIONS}

HABs can cause problems in marine ecosystems such as hypoxia and anoxia, as well as biotoxins producing which further accumulate in shellfish. On this way biotoxins became part of food chain and cause serious consequences, even fatal, in marine organisms and humans. Results obtained in this paper indicate that abundance of toxic and potentially toxic phytoplankton taxons is not alarmant, as well as biotoxins values bellow LOD, what implies on good quality of mussels meat on farm in Kamenari. Monitoring of harmful phytoplankton composition and biotoxins should be continued in future, so it can give the possibility to react on time in order to prevent negative consequences which can be caused by HABs and biotoxins.

\section{ACKNOWLEDGEMENT}

This study has been supported by the Ministry of Science of Montenegro and the HERIC project through the BIO-ICT Centre of Excellence (Contract No. 01-1001).

\section{REFERENCES}

AOAC (2005): Paralytic shellfish toxins in shellfish, Prechromatographic oxidation and liquid chromatography with fluorescence detection. AOAC International AOAC Official Method 2005.06.

Arapov, J. (2013): A review of shellfish phycotoxin profile and toxic phytoplankton species along Croatian coast of the Adriatic Sea. Acta Adriat., 54(2): 283-298.

Arapov, J., Skejić, S., Bužančić, M., Bakrač, A., Vidjak, O., Bojanić, N., Ujević, I. \& Ninčević-Gladan, Ž. (2017): Taxonomical diversity of Pseudo-nitzschia from the Central Adriatic Sea. Phycol. Res., doi:10.1111/pre.12184.

Bellafiore, D., Guarnieri, A., Grilli, F., Penna, P., Bortoluzzi, G., Giglio, F. \& Pinardi, N. (2011): Study of the hydrodynamical processes in the Boka Kotorska Bay with a finite element model. Dynam. Atmos. Ocean., 52(1-2): 298-321. 
Bortoluzzi, G., Giglio, F., Ligi, M., Del Bianco, F., Ferrante, V., Gasperini, L. \& Ravaioli, M. (2016): Morphobathymetry of Boka Kotorska Bay. In: A. Joksimović, M. Đurović, A.V. Semenov, I.S. Zonn, A.G. Kostianoy, eds. The Boka Kotorska Bay Environment, pp. 69-88. Springer International Publishing Cham, Switzerland. 606 pp.

Bosak, S., Horvat, L., Pestorić, B. \& Krivokapić, S. (2010): Observations on Pseudonitzschia species in the Bay of Kotor, SE Adriatic Sea. $39^{\text {th }}$ CIESM Congress, Venice, Italy. Conference proceedings: 721.

Bosak, S., Šilović, T., Ljubešić, Z., Kušpilić, G., Pestorić, B., Krivokapić, S. \& Viličić, D. (2011): Phytoplankton size structure and species composition as an indicator of trophic status in transitional ecosystems: the case study of a Mediterranean fjord-like karstic bay. Oceanologia, 54(2): 255-286.

Brooks, B.W., Lazorchak, J.M., Howard, M.D.A., Johnson, M.V., Morton, S.L., Perkins, D.A.K., Reavie, E.D., Scott, G.I., Smith, S.A. \& Steevens, J.A. (2016): Are harmful algal blooms becoming the greatest inland water quality threat to public health and aquatic ecosystems? Environ. Toxicol. Chem., 35(1): 6-13.

Burić, Z., Viličić, D., Caput-Mihalić, K., Carić, M., Kralj, K. \& Ljubešić, N. (2008): Pseudo-nitzschia blooms in the Zrmanja River estuary (Eastern Adriatic Sea). Diatom Res., 23(1): 51-63.

Cupp, E.E. (1943): Marine plankton diatoms of the west coast of North America. University of California, Cambridge University Press, UK. 238 pp.

Drakulović, D. (2012): Značaj fitoplanktona kao indikatora eutrofikacije u akvatorijumu Bokokotorskog zaliva. Doktorska disertacija. Biološki fakultet, Univerzitet u Beogradu. Beograd, Srbija. 227 pp.

Drakulović, D., Pestorić, B., Cvijan, M., Krivokapić, S. \& Vuksanović, N. (2012): Distribution of phytoplankton community in Kotor Bay (south-eastern Adriatic Sea). Cent. Eur. J. Biol., 7(3): 470-486.

Drakulović, D., Mandić, M., Joksimović, A. \& Petović, S. (2013): Distribution of phytoplankton on mussel farms in Boka Kotorska Bay. Stud. Mar., 26(1): 6582.

Drakulović, D., Pestorić, B., Joksimović, D., Redžić, A., Petović, S. \& Krivokapić, S. (2014): Dinoflagellate assemblages in Boka Kotorska Bay. Stud. Mar., 27(1): 65-83.

Drakulović, D., Pestorić, B., Joksimović, D., Marković, S. \& Mandić, M. (2015): Composition and distribution of diatoms on mussel farms in Boka Kotorska Bay. Stud. Mar., 28(1): 51-60.

Drakulović, D., Gvozdenović, S., Joksimović, D., Mandić, M. \& Pestorić, B. (2017): Toxic and potentially toxic phytoplankton in the mussel and fish farms in the transitional area of Montenegrin coast (South-Eastern Adriatic Sea). Turkish J. Fish. Aquat. Sci., 17(5): 885-900.

Dodge, D.J. (1985): Atlas of Dinoflagellates. Farrand Press, London, UK. 119 pp.

Estevez, P., Castro, D., Pequeño-Valtierra, A., Giraldez, J. \& Gago-Martinez, A. (2019): Emerging marine biotoxins in seafood from European coasts: Incidence and analytical challenges. Foods, 8(5): 149. 
Ferrante, M., Conti, G.O., Fiore1, M., Rapisarda, V. \& Ledda, C. (2013): Harmful algal blooms in the Mediterranean Sea: Effects on human health. EuroMediterranean Biomed. J., 8(6): 25-34.

Gvozdenović, S., Mandić, M., Drakulović, D. \& Joksimović, A. (2015): The shellfish biotoxins. Agric. For., 61(3): 135-142.

Gvozdenović, S., Mandić, M., Pešić, V., Nikolić, M., Pešić, A. \& Ikica, Z. (2017): Comparison between IMTA and monoculture farming of mussels (Mytilus galloprovincialis L.) in the Boka Kotorska Bay. Acta Adriat., 58(2): 271-284.

Hustedt, F. (1930): Kryptogamen-Flora: Die Kieselalgen Deuchelands, Österreich, und der Schweitz mit Berücksichtigung der übrigen Länder Europas sowie der angrenzenden Meeresgebiete. Teil 1. Akademiche Verlagsgesellschaft m.b.H., Leipzig, Denmark. 920 pp.

ISO 5667-9: 1992 (1992): Kvalitet vode. Uzorkovanje dio 9: Uputstvo za uzorkovanje morske vode.

Mandić, M., Ikica, Z. \& Gvozdenović, S. (2016): Mariculture in the Boka Kotorska Bay: Tradition, current state and perspective. In: A. Joksimović, M. Đurović, A.V. Semenov, I.S. Zonn, A.G. Kostianoy, eds. The Boka Kotorska Bay Environment, pp. 395-409. Springer International Publishing Cham, Switzerland. $606 \mathrm{pp}$.

Mandić, S., Radović, I. \& Radović, D. (2016): Physical and geographical description of the Boka Kotorska Bay. In: A. Joksimović, M. Đurović, A.V. Semenov, I.S. Zonn, A.G. Kostianoy, eds. The Boka Kotorska Bay Environment, pp. 43-67. Springer International Publishing Cham, Switzerland. 606 pp.

MEST EN 15204:2014 (2014): Kvalitet vode. Uputstvo za prebrojavanje fitoplanktona pomoću invertne mikroskopije (postupak po Utermolu).

Ninčević-Gladan, Ž., Matić, F., Arapov, J., Skejić, S., Bužančić, M., Bakrač, A., Straka, M., Dekneudt, Q., Grbec, B., Garber, R. \& Nazlić, N. (2020): The relationship between toxic phytoplankton species occurrence and environmental and meteorological factors along the Eastern Adriatic coast. Harmful Algae, 92: 101745.

Peragallo, H. \& Peragallo, M. (1965): Diatomees de France et des districts maritimes voisins. A. Asher et Co. (Reimpression), Amsterdam, Netherland. 539 pp.

Pestorić, B., Drakulović, D. \& Gvozdenović, S. (2019): Composition of microbiology, phytoplankton and biotoxins in water and mussel on fish and shellfish farms in Boka Kotorska Bay (SE Adriatic Sea). J. Agron. Technol. Eng. Manag., 2(1): 207-217.

Price, C., Black, K.D., Hargrave, B.T. \& Morris Jr, J.A. (2015): Marine cage culture and the environment: effects on water quality and primary production. Aquac. Environ. Interact., 6: 151-174.

Quilliam, M.A., Xie, M. \& Hardstaff, W.R. (1995): Rapid extraction and cleanup for liquid chromatographic determination of domoic acid in unsalted seafood. $J$. AOAC Int., 78(2): 543-554.

Schiller, J. (1933): Dinoflagellatae. Rabenhorst's Kryptogamenflora von Deutchland, Österrich und der Schweiz. Teil 1.617 pp.

Schiller, J. (1937): Dinoflagellatae. Rabenhorst's Kryptogamenflora von Deutchland, Österrich und der Schweiz. Teil 2. 589 pp. 
Sournia, A. (1989): Atlas du phytoplancton marine. Cyanophycées, Dictyochophycées, Dinophycées, Raphydophycées. Vol. 1. Editions du CNRS, Paris, France. 219 pp.

Ujević, I., Ninčević-Gladan, Ž., Roje, R., Skejić, S., Arapov, J. \& Marasović, I. (2010): Domoic acid - A new toxin in the Croatian Adriatic shellfish toxin profile. Molecules, 15(10): 6835-6849.

Utermöhl, H. (1958): For the supplement of quantitative phytoplankton methodology. Limnology, 9: 1-38.

Visciano, P., Schirone, M., Berti, M., Milandri, A., Tofalo, R. \& Suzzi, G. (2016): Marine biotoxins: Occurrence, toxicity, regulatory limits and reference methods. Front. Microbiol., 7: 1051.

Watson, S.B., Whitton, B.A., Higgins, S.N., Paerl, H.W., Brooks, B.W. \& Wehr, J. (2015): Harmful algal blooms. In: J. Wehr, R.G. Sheath, J.P. Kociolek, eds. Freshwater Algae of North America: Ecology and Classification, 2nd edition, pp. 871-918. Academic Press, Amsterdam. 1066 pp. 